OPEN ACCESS

Edited by:

Klaus Ley,

La Jolla Institute for Allergy and Immunology (LJI), United States

Reviewed by:

Zhichao Fan,

La Jolla Institute for Allergy and Immunology (LJI), United States

Alexandre Chigaev,

University of New Mexico,

United States

${ }^{*}$ Correspondence:

Eva M. Gálvez

eva@icb.csic.es

tThese authors share senior authorship.

Specialty section: This article was submitted

to Cytokines and Soluble

Mediators in Immunity,

a section of the journal

Frontiers in Immunology

Received: 06 April 2017 Accepted: 04 December 2017 Published: 21 December 2017

Citation:

Núñez D, Comas L, Lanuza PM,

Sánchez-Martinez D, PérezHernández M, Catalán E, Domingo MP, Velázquez-Campoy A, Pardo J and Gálvez EM (2017) A Functional Analysis on the Interspecies Interaction between Mouse LFA-1 and Human Intercellular Adhesion

Molecule- 1 at the Cell Level.

Front. Immunol. 8:1817. doi: 10.3389/fimmu.2017.01817

\section{A Functional Analysis on the Interspecies Interaction between Mouse LFA-1 and Human Intercellular Adhesion Molecule-1 at the Cell Level}

\author{
David Núñez 1,2,3, Laura Comas ${ }^{1,2,3}$, Pilar M. Lanuza ${ }^{1,2}$, Diego Sánchez-Martinez ${ }^{1,2}$, \\ Marta Pérez-Hernández ${ }^{1,2}$, Elena Catalán ${ }^{2}$, María Pilar Domingo ${ }^{3}$, \\ Adrián Velázquez-Campoy ${ }^{2,4,5}$, Julián Pardo ${ }^{1,5,6,7 \dagger}$ and Eva M. Gálvez ${ }^{1,3 *+}$ \\ 'Immune Effector Cells Group, Aragón Health Research Institute (IIS Aragón), Biomedical Research Centre of Aragón (CIBA) \\ Zaragoza, Spain, ${ }^{2}$ Department of Biochemistry and Molecular and Cell Biology, Fac. Ciencias, University of Zaragoza, \\ Zaragoza, Spain, ${ }^{3}$ Instituto de Carboquímica ICB-CSIC, Zaragoza, Spain, ${ }^{4}$ Institute of Biocomputation and Physics of \\ Complex Systems (BIFI), Unidad Asociada IQFR-CSIC-BIFI, Universidad de Zaragoza, Zaragoza, Spain, ${ }^{5}$ Aragón I + D \\ Foundation (ARAID), Government of Aragon, Zaragoza, Spain, ${ }^{6}$ Nanoscience Institute of Aragon (INA), University of \\ Zaragoza, Zaragoza, Spain, ${ }^{7}$ Department of Microbiology, Preventive Medicine and Public Health, University of Zaragoza, \\ Zaragoza, Spain
}

The interaction between intercellular adhesion molecules (ICAM) and the integrin leukocyte function-associated antigen-1 (LFA-1) is crucial for the regulation of several physiological and pathophysiological processes like cell-mediated elimination of tumor or virus infected cells, cancer metastasis, or inflammatory and autoimmune processes. Using purified proteins it was reported a species restriction for the interaction of ICAM-1 and LFA-1, being mouse ICAM-1 able to interact with human LFA-1 but not human ICAM-1 with mouse LFA-1. However, in vivo results employing tumor cells transfected with human ICAM-1 suggest that functionally mouse LFA-1 can recognize human ICAM1. In order to clarify the interspecies cross-reactivity of the ICAM-1/LFA-1 interaction, we have performed functional studies analyzing the ability of human soluble ICAM-1 and human/mouse LFA-1 derived peptides to inhibit cell aggregation and adhesion as well as cell-mediated cytotoxicity in both mouse and human systems. In parallel, the affinity of the interaction between mouse LFA-1-derived peptides and human ICAM-1 was determined by calorimetry assays. According to the results obtained, it seems that human ICAM-1 is able to interact with mouse LFA-1 on intact cells, which should be taking into account when using humanized mice and xenograft models for the study of immune-related processes.

Keywords: intercellular adhesion molecule-1, LFA-1, interspecies cross-reactivity, lymphocyte adhesion, integrins

Adhesion molecules are glycoproteins expressed on cell surfaces, where they mediate the contact between cell-cell, cell-extracellular matrix, and cell-pathogen. They are essential for physiological and pathological processes like embryonic development, wound healing, maintenance of tissue architecture, regulation of immune cell responses, migration of inflammatory cells into inflamed tissues, autoimmune diseases, and tumor metastasis $(1,2)$. Among the many molecules that regulate 
these processes, the interaction between the members of the intercellular adhesion molecule (ICAM) family and the integrin leukocyte function-associated antigen-1 (LFA-1, also known as CD11a/CD18) is especially relevant, ICAM-1 being the most extensively studied and best characterized member of ICAMs.

Intercellular adhesion molecule- 1 is a type I transmembrane cell-surface protein, belonging to the immunoglobulin superfamily, with a molecular weight of $80-120 \mathrm{kDa}$ depending on the level of glycosylation. The extracellular portion of ICAM-1 consists of 453 mainly hydrophobic amino acids, which form five immunoglobulin (Ig)-like domains. The extracellular region is attached to a single hydrophobic transmembrane region and a short cytoplasmic tail (3). ICAM-1 is the receptor for different human viruses like rhinovirus (4) and coxsackievirus A21 as well as for the malarial parasite Plasmodium falciparum (5) as well as different members of the integrin family like Mac-1 (6) and LFA-1 (7-10). Among them, the interaction with LFA-1 is the most critical step that mediates immune cell migration, activation, and target cell recognition.

Intercellular adhesion molecule- 1 is mainly expressed as a dimer on the cell surface and dimerization appears to enhance binding to LFA-1 (11). Nevertheless, each individual ICAM-1 monomer is fully competent to bind LFA-1 and dimerization seems to be dispensable to form a complete LFA-1-binding site (12). Although ICAM-1 is usually anchored to the membrane, a soluble ICAM-1 molecule (sICAM-1) has been identified in serum. sICAM-1 is presented in serum from healthy humans at concentrations between 100 and $450 \mathrm{ng} / \mathrm{ml}$ (13) and increased levels of sICAM-1 have been found in serum from patients with cardiovascular and inflammatory diseases as well as during cancer metastasis $(14,15)$.

LFA-1 is a heterodimeric glycoprotein comprising a $\alpha \mathrm{L}$ (CD11a, $180 \mathrm{kDa})$ and $\beta_{2}(\mathrm{CD} 18,95 \mathrm{kDa})$ subunits that are noncovalently linked. Both domains have a complex structure that includes large extracellular domains, single-pass transmembrane segments, and short intracellular tails (16). The $\alpha$ subunit of LFA-1 $(\alpha L)$ contains an N-terminal stretch of 200 amino acids, the inserted (I) or A domain, that is crucial for the ligand-binding specificity (17). A metal ion-dependent adhesion site (MIDAS) is located in the upper face of the I-domain (18). ICAM-1 interacts with LFA-1 through the binding of its first Ig-domain $\left(D_{1}\right)$ with the MIDAS within the I-(inserted) domain at the top of the N-terminus of $\alpha$ L subunit of LFA-1 (19). The ICAM-1/LFA-1 interaction is facilitated by magnesium and manganese divalent cations, assorted with five amino acids of MIDAS in LFA-1 and glutamate in domain 1 of ICAM-1 (20).

Interaction of LFA-1 in lymphocytes with ICAM-1 in target cells critically regulates all steps involved in the immune response including homing of lymphocytes, monocytes, and granulocytes during the inflammatory responses, Ag presentation, $\mathrm{T}$ helper and $\mathrm{B}$ lymphocyte responses, and $\mathrm{T}$ and natural killer (NK) cell-mediated killing $(21,22)$. In addition, it has been involved in several pathologies like metastasis of cancer cells or cardiovascular and autoimmune diseases.

Humanized mice are widely used as in vivo models to study the molecular basis of immune-related disorders as well as the efficacy of potential drugs (23). In these mice, the native gene of interest is replaced by its human homolog or the immune system is eliminated and reconstituted with its human counterpart. In addition, these mice can be used to enhance the engraftment of human cancer cells allowing in vivo studies of cancer progression and treatment. Here, a major obstacle to analyze human cell function, either healthy or transformed, and disease is the lack of species cross-reactivity of many growth factors, cytokines, or ligands required for development, survival, and function of the human grafted tissue/cells. Most of the cell adhesion molecules involved in leukocyte function are conserved across species. However, some of them like CD2 differ in tissue distribution and ligands $(24,25)$. LFA-I and ICAM-1 are well conserved across species including tissue distribution, ligands, and function (26-28). However, using purified cell-free models, it has been described that mouse ICAM-1 binds human LFA-1, but human ICAM-1 does not bind mouse LFA-1 (29). In contrast, other groups have shown that in vivo control of cancer development by mouse immune system is enhanced by expression of human ICAM-1 (30-32). Later, it was reported that murine LAK cells kill more efficiently mouse tumor cells transfected with human ICAM-1 than parental non-transfected cells (33). These results suggest a functional binding of human ICAM-1 to mouse LFA-1.

As indicated, homing and effector function of immune cells as well as cancer metastasis are critically regulated by LFA-1/ ICAM-1 interaction and, thus, clarifying the species crossreactivity of these molecules is crucial to support the utility of humanized mice in immune-related pathologies and cancer and to understand the results thereof. Here, we provide the functional experimental evidence showing that human ICAM-1 is able to interact with mouse LFA-1 during immune cell adhesion and cell cytotoxicity.

\section{EXPERIMENTAL PROCEDURES}

\section{ICAM-1 Chimeras and LFA-1-Derived Peptides}

The synthetic first two domains of ICAM-1 alone $\left(D_{1} D_{2}\right)$ or linked with human IgG1 Fc region $\left(\mathrm{D}_{1} \mathrm{D}_{2} \mathrm{Fc}\right)$ were expressed in Escherichia coli and purified by single step column refolding as described (34). We have previously shown that the affinity of the interaction of human $\mathrm{D}_{1} \mathrm{D}_{2} \mathrm{Fc}$ with human LFA-1 is similar to a chimera formed by the five extracellular domains of ICAM-1, $\mathrm{D}_{1} \mathrm{D}_{5} \mathrm{Fc}$ (35). Mouse and human Fc chimeras containing the five extracellular domains of ICAM-1 $\left(\mathrm{D}_{1} \mathrm{D}_{5} \mathrm{Fc}\right)$ were purchased in R\&D systems.

Human and mouse LFA-1-derived peptides (human:

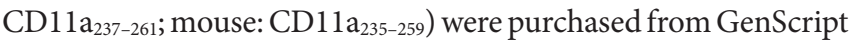
(Piscataway, USA) without any modification. The sequences of

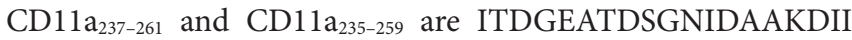
RYIIGI and ITDGEASDKGNISAAHDITRYIIGI, respectively, and have been previously characterized in basis of its ability to block ICAM-1/LFA-1 interaction (36).

\section{Mouse Strains}

Mice (C57BL/6J) between 5 and 7 weeks of age were used. These mice were maintained and bred in pathogen-free conditions in 
the animal facility of the Center for Agriculture Research and Technology (CITA) of the Government of Aragón. Mice were maintained on a $12 \mathrm{~h}$ light-dark cycle. Each cage contained aspen woodchip bedding (Capsumlab) and nesting material (shredded paper), and food (Harlan Laboratories) and tap water were provided ad libitum.

All procedures were approved by the Ethic Committee for Animal Experiments from CITA. The care and use of animals were performed accordingly with the Spanish Policy for Animal Protection RD53/2013, which meets the European Union Directive 2010/63 on the protection of animals used for experimental and other scientific purposes.

\section{Isothermal Titration Calorimetry (ITC)}

The ability of the human chimera $\mathrm{D}_{1} \mathrm{D}_{2} \mathrm{Fc}$ to interact with a peptide derived from its natural ligand LFA-1 in mouse was analyzed by ITC on a VP-ITC calorimeter (MicroCal) at $25^{\circ} \mathrm{C}$ as indicated previously (34). Briefly, $2.2 \mathrm{ml}$ of a $12-\mu \mathrm{M}$ solution of $\mathrm{D}_{1} \mathrm{D}_{2} \mathrm{Fc}$ and $0.5 \mathrm{ml}$ of a $150-\mu \mathrm{M}$ solution of peptide were prepared in PBS and degassed. Each assay consisted of a series of 28 injections of peptide solution of $10 \mu \mathrm{l}$ each (with a 4 - $\mu$ l first injection) at $400 \mathrm{~s}$ intervals under constant stirring (459 rpm). The thermal power required to keep the cell at a constant temperature is measured, so that it provides the heat associated with each ligand injection after integrating the signal over time. The thermodynamic parameters of protein-peptide interactions (affinity, enthalpy, and entropy changes) as well as the stoichiometry were estimated by using nonlinear regression analysis. Data were analyzed using the software developed and implemented in Origin 7.0 (OriginLab).

\section{Analysis of ICAM-1 and LFA-1 Interaction by Flow Cytometry}

The ability of human $\mathrm{D}_{1} \mathrm{D}_{2} \mathrm{Fc}$ and mouse and human $\mathrm{D}_{1} \mathrm{D}_{5} \mathrm{Fc}$ to recognize LFA-1 on mouse cells was analyzed by flow cytometry in the mouse thymic lymphoma cell line EL4. EL4 cells were incubated with different concentrations of human $\mathrm{D}_{1} \mathrm{D}_{2} \mathrm{Fc}$, mouse and human $\mathrm{D}_{1} \mathrm{D}_{5} \mathrm{Fc}$ and human IgG1 control at $4^{\circ} \mathrm{C}$ for $45 \mathrm{~min}$, washed twice with FACS buffer (PBS, 5\% FCS, $0.1 \% \mathrm{NaN}_{3}$ ), and then incubated with PE-conjugated goat anti-human IgG (Fcy fragment specific; Jackson ImmunoResearch). After a washing step with FACS buffer, cells were analyzed by FACS using a FACS Calibur with CellQuest Pro software (BD). As control cells were incubated with an antibody against mouse CD11a (LFA-1) before adding human $\mathrm{D}_{1} \mathrm{D}_{2} \mathrm{Fc}$.

\section{Human and Mouse Macrophage Differentiation}

Monocytes were isolated from human peripheral blood mononuclear cells (PBMCs), obtained from healthy donors (Blood and Tissue Bank of Aragon; approved by the CEICA, number: C.I.PI11/006) by density gradient centrifugation using FicollPaque (GE healthcare). PBMCs were resuspended at a concentration of $2.5 \times 10^{6}$ cells $/ \mathrm{ml}$ in RPMI medium supplemented with $1 \%$ heat-inactivated human $\mathrm{AB}$ serum (Sigma). Cells were cultured in a Petri dish for $2 \mathrm{~h}$ at $37^{\circ} \mathrm{C} 5 \% \mathrm{CO}_{2}$. Then cells were carefully washed twice with PBS, and RPMI medium supplemented with $10 \%$ FBS, 2 mM L-glutamine, and antibiotics (penicillin $100 \mathrm{U} / \mathrm{ml}$, streptomycin $100 \mu \mathrm{g} / \mathrm{ml}$ ) (complete RPMI medium) was added and cells were further incubated for $2 \mathrm{~h}$ at $37^{\circ} \mathrm{C} 5 \% \mathrm{CO}_{2}$. Cells were washed again with PBS and complete RPMI medium supplemented with GM-CSF (Invitrogen) at a concentration of $0.1 \mathrm{ng} / \mathrm{ml}$ was added. Cell culture was maintained for 6 days until monocytes are differentiated into macrophages. Macrophage differentiation was confirmed by microscopic evaluation under light microscope and by immunophenotypical characterization using the following antibodies from BD Pharmingen: HLA-DR-PE, CD14-FITC, ICAM-1FITC, and LFA-1-APC.

Mouse macrophages were differentiated from mouse bone marrow as previously described (37). Briefly, bone marrow cells isolated from mouse femur were cultured in DMEM 10\% FBS, 5\% horse serum, and 30\% supernatant of L929 cell culture as a source of M-CSF at a density of $10^{6} / \mathrm{cm}^{2}$ for $7-8$ days. Macrophage differentiation was analyzed in the same way as human macrophages but using CD11b-APC and CD11c-PE (BD) antibodies.

\section{Cell Adhesion Assays}

Freshly isolated monocytes or differentiated macrophages were washed twice with PBS and incubated with trypsin (PAN Biotech) for $30 \mathrm{~min}$ at $37^{\circ} \mathrm{C} 5 \% \mathrm{CO}_{2}$. After that, cells were scraped gently from the plate and resuspended at a final concentration of $10^{6}$ cells $/ \mathrm{ml}$ in complete RPMI medium. Subsequently, $10^{5}$ macrophages and $5 \times 10^{5}$ monocytes were added to each well and incubated with several concentrations of human $\mathrm{D}_{1} \mathrm{D}_{2}$, $\mathrm{D}_{1} \mathrm{D}_{2} \mathrm{Fc}, \mathrm{D}_{1} \mathrm{D}_{5} \mathrm{Fc}$, mouse $\mathrm{D}_{1} \mathrm{D}_{5} \mathrm{Fc}$, control human IgG1 $20 \mu \mathrm{g}$ or lovastatin $100 \mu \mathrm{M}$ at $37^{\circ} \mathrm{C} 5 \% \mathrm{CO}_{2}$ overnight. Next day, every well was washed twice with PBS, complete RPMI medium was added and the number or adherent remaining cells was quantified by a MTT colorimetric test (38). In some experiments, plates previously coated with human and mouse $\mathrm{D}_{1} \mathrm{D}_{5} \mathrm{Fc}$ were used. To coat the plates $5 \mu \mathrm{g}$ of $\mathrm{D}_{1} \mathrm{D}_{5} \mathrm{Fc}$ in $100 \mu \mathrm{l}$ of PBS was incubated overnight at $4^{\circ} \mathrm{C}$ and subsequently plates were washed with PBS and blocked with $1 \%$ BSA in PBS for $2 \mathrm{~h}$ at room temperature.

\section{NK Cell-Mediated Cytotoxicity}

The effect of human and mouse peptides derived from LFA-1 on ICAM-1/LFA-1 dependent cell-cell contact was analyzed by performing a cell cytotoxicity assay using human primary NK cells and the NK cell sensitive human leukemia K562. Primary activated human NK cells were generated by culturing PBMCs with mitomycin C inactivated R69 cells for 5 days and enriched by MACS using anti-CD56 antibodies as previously described (39). Cell cytotoxicity induced by NK cells on K562 was analyzed by flow cytometry as previously described (39). Briefly, K562 cells were preincubated with medium alone, in the presence of $250 \mu \mathrm{M}$ of human and mouse peptides from LFA-1 or $\mathrm{D}_{1} \mathrm{D}_{2}(15 \mu \mathrm{g})$ for $45 \mathrm{~min}$ at $37^{\circ} \mathrm{C}$. Then, NK cells were added at 3:1 effector:target cell ratio and incubated for $4 \mathrm{~h}$ at $37^{\circ} \mathrm{C}, 5 \% \mathrm{CO}_{2}$. Subsequently, phosphatidylserine exposure and 7-AAD uptake were analyzed by FACS using the annexin-V/7-AAD kit from 
Immunostep. As a control, the cells were incubated alone with the inhibitors to evaluate their possible toxicity, which was not significant in any case.

\section{CD8 $^{+}$T Cell-Mediated Cytotoxicity}

To check whether the human chimeras of ICAM-1 and human and mouse peptides from LFA-1 were able to recognize their counterpart in mouse cells, a cytotoxicity assay with lymphocytic choriomeningitis virus (LCMV)-specific CD8 ${ }^{+} \mathrm{T}$ cells generated in vivo and EL4 cells as targets as previously described (40) was carried out. Mice were inoculated intraperitoneally (i.p.) with $10^{5}$ plaque-forming units LCMV-WE in $200 \mu \mathrm{l}$. At day 8 post-infection, mice were sacrificed by cervical dislocation, the spleens were removed, splenocytes were isolated, and CD8 cell fraction was enriched by MACS, using anti-CD8-MicroBeads (Miltenyi Biotec). Subsequently, CD8 cells were resuspended in RPMI medium 5\% decomplemented FBS and preincubated in the presence of several concentrations of human $D_{1} D_{2}$, $\mathrm{D}_{1} \mathrm{D}_{2} \mathrm{Fc}$, mouse $\mathrm{D}_{1} \mathrm{D}_{5} \mathrm{Fc}, 250 \mu \mathrm{M}$ of human and mouse LFA-1 derived peptides, human IgG1 $15 \mu \mathrm{g}$ and lovastatin $100 \mu \mathrm{M}$ for $45 \mathrm{~min}$ at $37^{\circ} \mathrm{C} 5 \% \mathrm{CO}_{2}$. EL4 cells were previously incubated for $2 \mathrm{~h}$ at $37^{\circ} \mathrm{C} 5 \% \mathrm{CO}_{2}$ with $1 \mu \mathrm{M}$ of the immunodominant peptide of LCMV, KAVYNFATM (gp33, NeoMPS). Then, CD8 cells and EL4 target cells were incubated at ratio effector:target 10:1 in 96-well plate conical bottom for $4 \mathrm{~h}$ at $37^{\circ} \mathrm{C} 5 \% \mathrm{CO}_{2}$. Subsequently, phosphatidylserine exposure and 7-AAD uptake were analyzed by FACS using the annexin-V/7-AAD kit from Immunostep. As a control, EL4 cells and CD8 lymphocytes were incubated in the absence of gp33. In addition, in both cases, the cells were incubated alone with the inhibitors to evaluate their possible toxicity, which was not significant in any case.

\section{B Cell Aggregation Assay}

The ability of human and mouse peptides from LFA-1 and human ICAM-1 to inhibit cell homotypic aggregation was analyzed by using mouse B cells. To obtain these cells, mice were sacrificed by cervical dislocation, the spleens were removed, and splenocytes were isolated and resuspended in RPMI 10\% FBS at a final concentration of $10^{6}$ cells $/ \mathrm{ml}$. Cells were treated with $10 \mu \mathrm{g} / \mathrm{ml}$ PHA and $1 \mu \mathrm{g} / \mathrm{ml}$ ionomycin to activate LFA- 1 and incubated at $37^{\circ} \mathrm{C} 5 \% \mathrm{CO}_{2}$ overnight in flat bottom 96 -well plates $\left(10^{5}\right.$ cells $)$ in the presence of peptides from LFA- 1 and c-Myc (control) $250 \mu \mathrm{M}, \mathrm{D}_{1} \mathrm{D}_{2}, \mathrm{D}_{1} \mathrm{D}_{2} \mathrm{Fc}$, and human IgG1 $10 \mu \mathrm{g}$, EGTA $1 \mathrm{mM}$ and lovastatin $100 \mu \mathrm{M}$. A qualitative aggregation assay was carried out as described $(36,41)$ with a slight modification. Briefly, positive control stimulated cell samples were arbitrarily assigned a clumping index of 10 and lovastatin samples an index of 1 . Test samples were ranked from 1 to 10 based upon degree of clumping relative to stimulated and lovastatin-treated samples. Results were verified by a blind independent rating performed by a second observer.

\section{Statistic Analysis}

Statistical analysis was performed using GraphPad Prism software (GraphPad, San Diego, CA, USA) by two-way analysis of variance, followed by Bonferroni's posttest.

\section{RESULTS AND DISCUSSION}

\section{Interaction between Human ICAM-1 and Mouse Derived LFA-1 Peptides by ITC}

In a previous work, we have shown that purified human recombinant ICAM-1 was able to interact with peptides derived from human LFA-1 (34). In order to test whether mouse LFA-1 contained sequences that are able to recognize human ICAM-1, we have now analyzed by ITC the interaction between human ICAM-1 and a peptide derived from mouse LFA-1. This peptide contains the sequence of mouse LFA-1 corresponding to the peptide of human LFA-1 that showed the highest affinity for human ICAM-1 (34).

As shown in Figure 1, the curvature of the binding isotherm implies a high affinity for $\mathrm{D}_{1} \mathrm{D}_{2} \mathrm{Fc}\left(K_{\mathrm{D}}=70 \mathrm{nM}\right)$ similar to the one observed previously with a peptide derived from human LFA-1 (34). The complex formation was net exothermic as would be expected for a reaction in which specific intermolecular interactions are established. Besides, if there were no interaction, there would not be any signal. This value was obtained by fitting to the binding isotherm a 1:n interaction model, which assumes a single type of binding sites. This result indicates that mouse LFA-1 contains sequences that could interact with human ICAM-1 and suggests that mouse LFA-1 could potentially bind human ICAM-1.

\section{Binding of Human ICAM-1 with Cell- Associated Mouse LFA-1}

Isothermal titration calorimetry experiments suggest that human ICAM-1 is able to recognize a specific sequence derived from $\alpha$ Idomain of the mouse integrin LFA-1 corresponding to the area of attachment to ICAM-1. However, although mouse LFA-1 derived short peptides have a high sequence homology in their counterpartner in human and human ICAM-1 is capable of recognizing

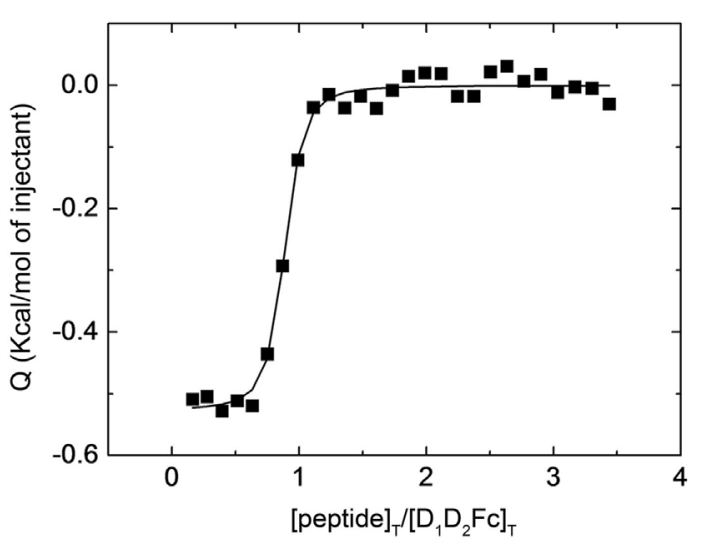

FIGURE 1 | Interaction of LFA-1 peptide with $D_{1} D_{2} F_{C}$ by isothermal titration calorimetry. Purified $\mathrm{D}_{1} \mathrm{D}_{2} \mathrm{Fc}_{\mathrm{c}}(12 \mu \mathrm{M})$ was titrated with a peptide derived from the binding site of mouse LFA-1 (CD11 $\left.\mathrm{a}_{235-259 ;} ; 50 \mu \mathrm{M}\right)$. The assay was performed in PBS buffer at $25^{\circ} \mathrm{C}$. The nonlinear regression analysis done as described in Section "Experimental Procedures" provided a dissociation constant of $70 \mathrm{nM}$. 
them, these linear amino acid sequences do not completely mimic the interaction among proteins containing a three-dimensional spatial structure. Thus, to prove that human ICAM-1 is capable of interacting with mouse LFA-1, we have analyzed the ability of the purified protein to bind the native form of LFA-1 expressed on the plasma membrane of mouse lymphoid cells. To this aim, we tested the interaction of $\mathrm{D}_{1} \mathrm{D}_{2} \mathrm{Fc}$ and LFA- 1 in the mouse T cell line EL4 which express high levels of LFA-1 (data not shown) by flow cytometry (Figure 2A).

As shown in Figure 2A, the percentage of positive cells increases as it increases the amount of ICAM-1 chimera added, indicating that human ICAM-1 is able to recognize and bind to mouse LFA-1 in compare with the negative control IgG. Incubation cells with a mouse antiCD11a (LFA-1) antibody blocked binding of the chimera.

To analyze the binding affinity of human ICAM-1 to mouse LFA-1, we compared the binding of mouse $\mathrm{D}_{1} \mathrm{D}_{5} \mathrm{Fc}$ and human
$\mathrm{D}_{1} \mathrm{D}_{5} \mathrm{Fc}$ to EL4 cells. As shown in Figure 2B, both human and mouse ICAM-1 bound to EL4 cells, although in this case binding of human ICAM-1 was higher than binding of mouse ICAM-1.

To further evaluate and confirm that human ICAM-1 was able to interact with mouse LFA-1 in other cell types, we analyzed the ability of human ICAM- $1\left(\mathrm{D}_{1} \mathrm{D}_{2} \mathrm{FC}\right.$ and $\left.\mathrm{D}_{1} \mathrm{D}_{2}\right)$ to block $\mathrm{B}$ cell aggregation by using a homotypic cell aggregation assay. Homotypic B cell aggregation is mostly due to ICAM-1/LFA-1 interaction and this assay is widely used to analyze the affinity of LFA-1 and/or ICAM-1 ligands (7).

Fresh mouse B cells were obtained from splenocytes and stimulated with PHA and ionomycin to induce homotypic adhesion. The images of cell aggregation assay are shown in Figure 3A, $\mathrm{a}-\mathrm{i}$. The results were quantified by establishing a clumping index that represents the degree of cell aggregation, which reflects the inhibition efficiency (Figure 3B). Cell aggregation was ranked by a clumping index from 1 to 10 based on the degree of aggregation
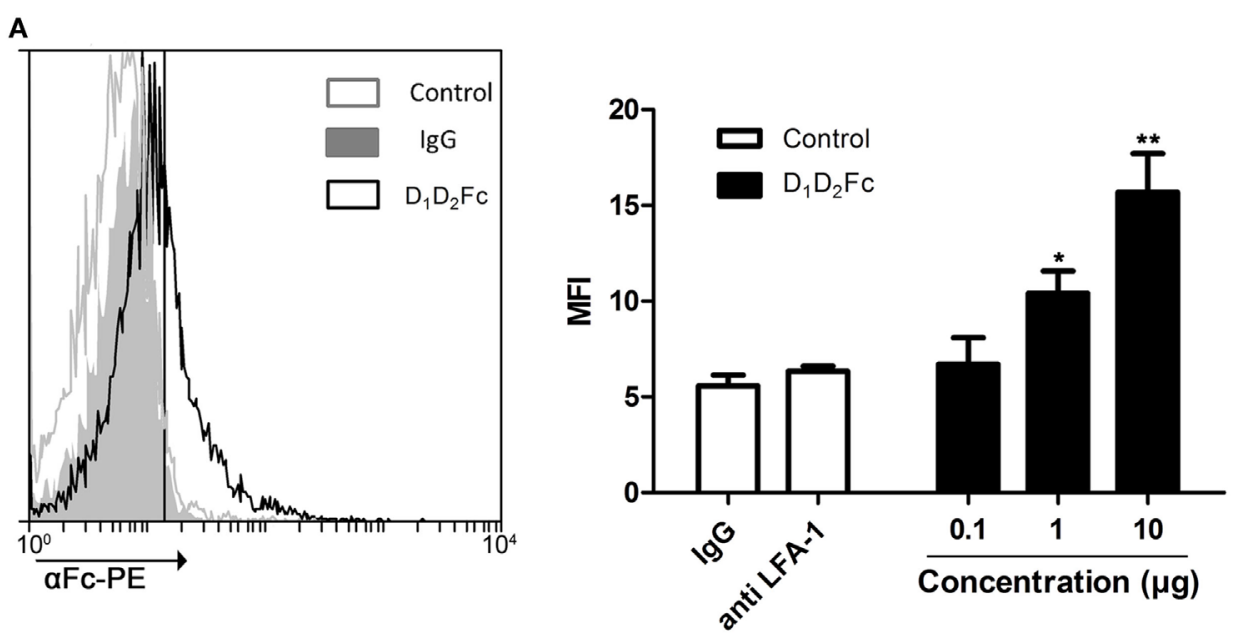

B
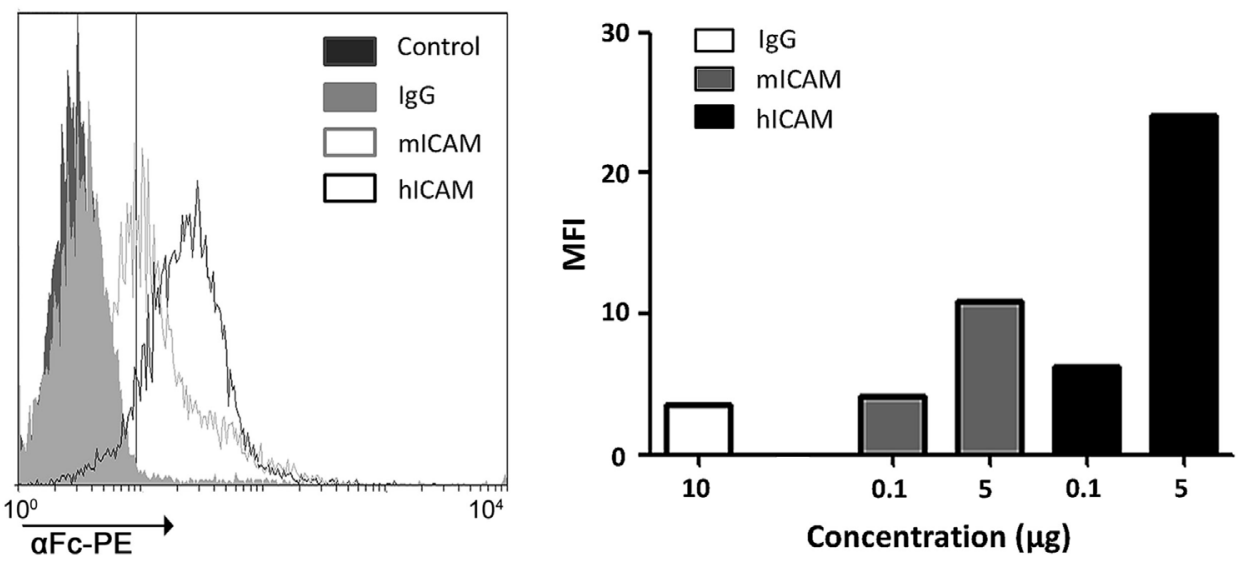

FIGURE 2 | Analysis of $D_{1} D_{2} F c$ binding to LFA-1 in EL4 cells by flow cytometry. (A) Different amounts of $D_{1} D_{2} F c(0.1,1$, and $10 \mu g)$ or human lgG1 control (10 $\mu$ g) were incubated with EL4 cells. After washing out non-bound proteins, cells were incubated with PE-conjugated goat anti-human IgG Fc $\gamma$ Ab and analyzed by flow cytometry. As a control EL4 cells were pretreated with a mouse LFA-1 blocking antibody (anti LFA-1) before incubating with $10 \mu \mathrm{g}$ of $\mathrm{D}_{1} \mathrm{D}_{2} \mathrm{Fc}$. Histograms show a representative experiment. Values in the graph are represented as mean \pm SEM of two independent experiments performed by duplicate. Statistical analysis was performed with two-way analysis of variance with Bonferroni's posttest by comparing IgG with $\mathrm{D}_{1} \mathrm{D}_{2} \mathrm{Fc}$. ${ }^{*} p<0.05$; ${ }^{\star \star} p<0.01$. (B) Different amounts of mouse or

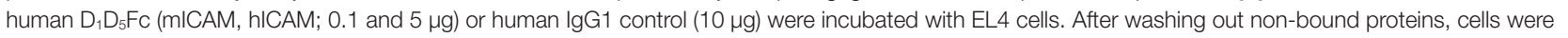
incubated with PE-conjugated goat anti-human IgG Fcy Ab and analyzed by flow cytometry. Histograms show a representative experiment. 


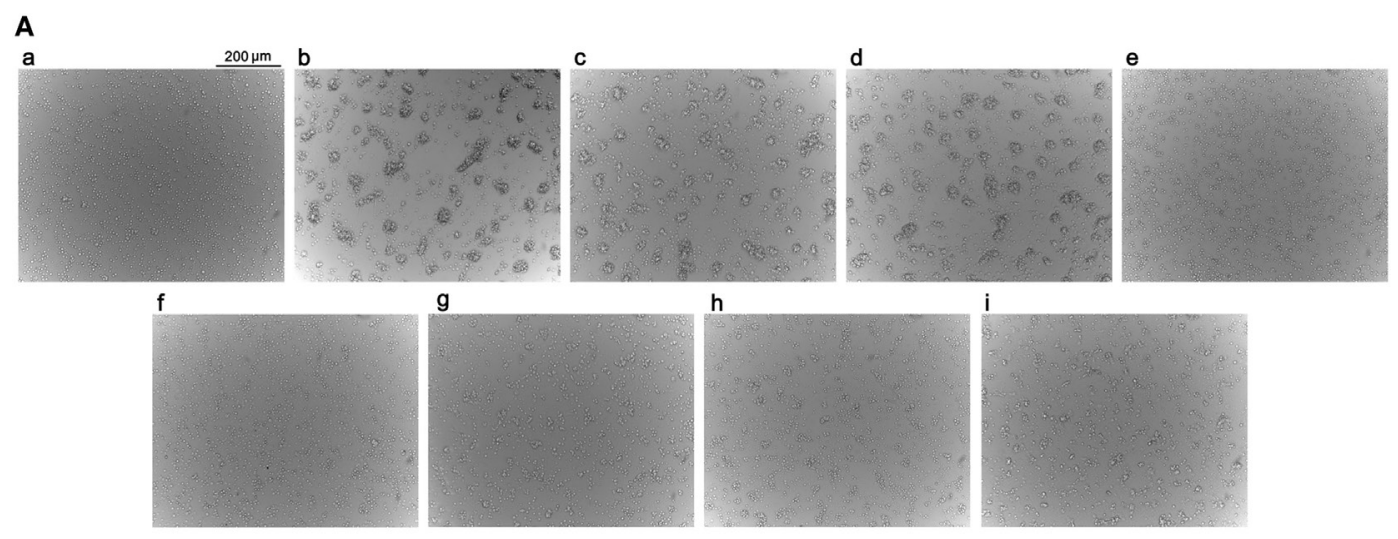

B

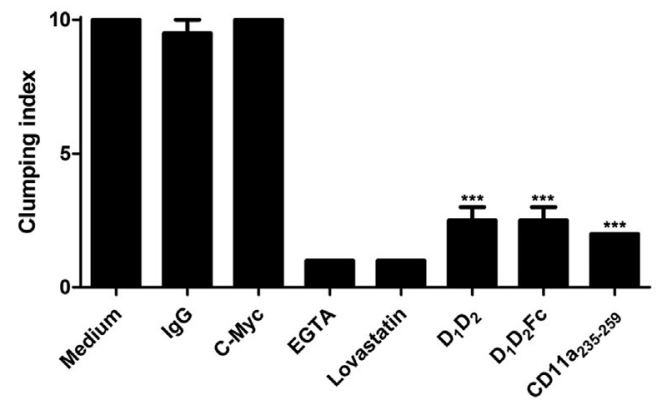

FIGURE 3 | Effect of human (ICAM-1) on the aggregation of mouse spleen cells. (A) Splenocytes isolated from mice were non treated (a) or activated with PHA (b-i) as described in Section "Experimental Procedures" and further incubated overnight with (b) medium; (c) IgG1; (d) c-Myc peptide; (e) EGTA; (f) lovastatin; (g) $D_{1} D_{2}$; (h) $D_{1} D_{2} F c$; (i) mouse LFA-1 peptide CD11 $a_{235-25}$. Images were taken with an optical microscope (original magnification, 10x). Representative images from two independent experiments with similar results are shown. (B) The graph represents the rate of agglutination depending on the inhibitory effect on ICAM-1/ LFA-1 interaction. Cells stimulated with PHA and ionomycin, which served as a positive control, were arbitrarily assigned agglutination index 10, which represents a percentage of aggregation between 90 and 100\%. Homotypic aggregation was classified from 1 to 10 depending on the degree of aggregation relative to cells stimulated. The result was verified by a second independent observer. Values are presented as mean \pm SEM of two separate experiments performed by duplicate. Statistical analysis was performed using two-way analysis of variance with Bonferroni's posttest comparing with $c-$ Myc peptide control. ${ }^{*} p<0.05$; ${ }^{* * *} p<0.001$.

in comparison with the stimulated cells (positive control, clumping index $=10$ ).

As expected, non-stimulated fresh $\mathrm{B}$ cells did not aggregate in culture (Figure 3A, a). In contrast, cell aggregates were clearly visible in cultures after stimulation (Figure 3A, b). As controls, the cation chelator EGTA and the drug lovastatin (Figure 3A), which have been described to specifically block ICAM-1/LFA-1 interaction without affecting other adhesion molecules such a Mac-1 or VLA-4 $(42,43)$, were able to inhibit completely the aggregation, while human IgG1 and a peptide derived from c-Myc (Figure 3A, c,d) did not present any effect. Besides, incubation cells with a mouse antiCD11a (LFA-1) antibody blocked aggregation (data not shown). Human ICAM-1 (Figure 3A, g,h) significantly inhibited adhesion at concentration of $10 \mu \mathrm{g}$ confirming that, as in the case of T cells, human ICAM-1 interacts with mouse LFA-1 in B cells. The mouse LFA-1 derived peptide (Figure 3A, i) completely blocked B cell aggregation confirming that this process was dependent on ICAM-1/LFA-1 interaction.

Our data using intact mouse cell expressing LFA-1 contrast with a previous work indicating that human ICAM-1 did not bind to mouse LFA-1 (29). Two explanations could account for these a priori contradictory results: (i) the previous work was performed

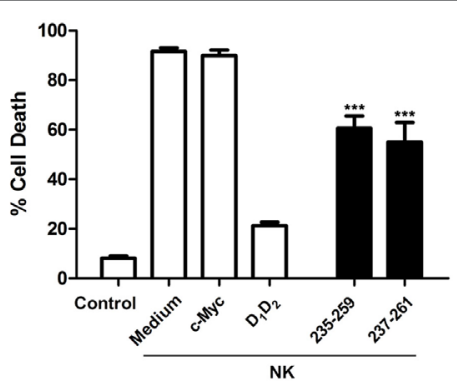

FIGURE 4 | Inhibition of natural killer (NK) cell-mediated cytotoxicity by human intercellular adhesion molecule-1. Human NK cells isolated from healthy donors were activated and enriched by MACS as described in Section "Experimental Procedures" and labeled with the fluorescent probe CFSE. Subsequently they were incubated with K562 cells at effector:target (e:t) ratio $3: 1$ for $4 \mathrm{~h}$ in the presence or absence of human $D_{1} D_{2}$ or mouse LFA-1 peptide CD11 $\mathrm{a}_{235-259}(250 \mu \mathrm{M})$, human LFA-1 peptide CD11 $\mathrm{a}_{237-261}$ $(250 \mu \mathrm{M})$, and c-Myc peptide as control. Cell death was analyzed by measuring translocation of PS by flow cytometry in the negative population for CFSE as described in experimental procedures. Values are presented as mean \pm SEM of two independent experiments performed by duplicate. Statistical analysis was performed using two-way analysis of variance with Bonferroni's posttest comparing with $c-M y c$ control. ${ }^{*} p<0.05 ;{ }^{* \star *} p<0.001$. 
using purified proteins and was not confirmed in intact cells or (ii) human ICAM-1 is binding to other integrins in EL4 or B cells like Mac-1. However, this is discarded since Mac-1 would bind to domain 3 in ICAM-1 and the proteins used here only consist of the first two domains. Thus, our results suggest that the interaction between human ICAM-1 and mouse LFA-1 in intact cells is different from that observed using purified proteins. Our data are in line with previous works suggesting that mouse LFA-1 interact with target cells expressing human ICAM-1 (30-32).

\section{Blocking of Cell-Mediated Cytotoxicity}

As above mentioned, it has been previously reported that elimination of target cells by mouse cytotoxic lymphocytes is enhanced by overexpression of human ICAM suggesting that mouse LFA-1 is interacting with human ICAM-1 (33). Upon recognition of target cells, cytolytic leukocytes, $\mathrm{NK}$, and mouse cytotoxic $\mathrm{CD}^{+} \mathrm{T}(\mathrm{Tc})$ cells, adhere to target cells before antigen recognition takes place (44), and these cells might utilize regulated changes in adhesion to control immune recognition events (45). The main adhesion molecule that plays a key role in the interaction with target cells is ICAM-1. The interaction of ICAM-1, expressed on tumor target cells, with LFA-1, expressed on the membrane of NK cells and Tc cell, modulates the formation and signaling of the immunological synapse and the subsequent elimination of the target cell (46).

First of all, we analyzed if the mouse LFA-1 derived peptide was able to block human NK cells mediated cytotoxicity on human K562 leukemic cells. As shown in Figure 4, this peptide was able to significantly inhibit cell death induced by human NK cells on the human leukemia cell line K562. This finding indicates that the peptide from mouse LFA-1 binds to human ICAM-1 in K562 cells preventing its interaction with LFA-1 on NK cells. As expected, a peptide derived from human LFA-1 as well as purified human ICAM-1 $\left(\mathrm{D}_{1} \mathrm{D}_{2}\right)$ blocked NK cell-mediated cell death confirming the participation of ICAM-1/LFA-1 interaction in this process. Here, we only analyzed the effect of $\mathrm{D}_{1} \mathrm{D}_{2}$ to avoid a potential antibody dependent cell cytotoxicity effect when employing $\mathrm{D}_{1} \mathrm{D}_{2} \mathrm{Fc}$ quimera.
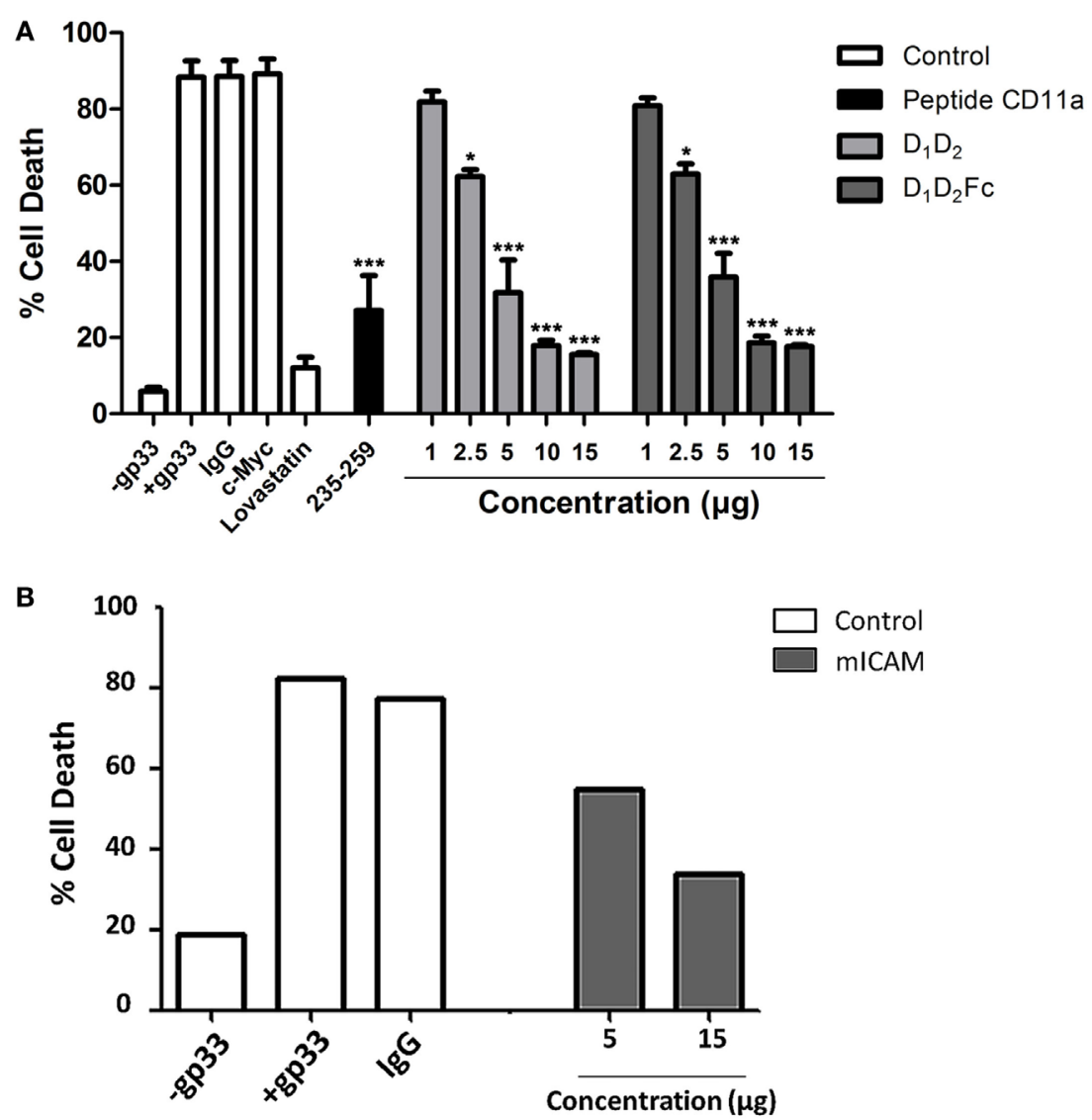

FIGURE 5 | Inhibition of cytotoxic CD8 ${ }^{+}$T cell-mediated cytotoxicity. (A) CD8 ${ }^{+}$cells were isolated by MACS from mice previously infected with lymphocytic choriomeningitis virus as described in Section "Experimental Procedures" and labeled with the fluorescent probe CTG. Subsequently they were incubated with EL4 cells previously labeled with gp33 viral peptide at a e:t ratio 10:1 for $4 \mathrm{~h}$ in the presence or absence of different concentrations of human $D_{1} D_{2}$ and $D_{1} D_{2} F_{C}$, mouse LFA-1 peptide CD11 2 $_{235-259}$, C-Myc $250 \mu \mathrm{M}$, IgG $15 \mu \mathrm{g}$, and lovastatin $100 \mu \mathrm{M}$. Cell death was analyzed by measuring translocation of PS by flow cytometry in the negative population CTG as described in experimental procedures. Values are presented as mean \pm SEM of three independent experiments performed by duplicate. Statistical analysis was performed using two-way analysis of variance with Bonferroni's posttest compared to the control lgG1 and c-Myc peptide for protein and the peptide, respectively. ${ }^{*} p<0.05$; ${ }^{\star \star \star} p<0.001$. (B) The same experiment as in (A) was performed but employing mouse intercellular adhesion molecule-1 (mICAM, $\left.\mathrm{D}_{1} \mathrm{D}_{5} \mathrm{FC}\right)$. 
Next, we employed mouse Tc cells to analyze the effect of human purified ICAM-1 on its cytotoxic function. We have tested if human purified ICAM-1 was able to block cell death induced by LCM virus-specific Tc cells on mouse EL4 cells that express high levels of ICAM-1 (data not shown). As shown in Figure $\mathbf{5 A}$, incubation with increasing amounts of human ICAM-1 completely blocked cell death induced by mouse Tc cells on LCMV gp33 antigen pulsed EL4 cells indicating that human ICAM-1 is interacting with mouse Tc cell-associated LFA-1 and preventing its binding to ICAM-1 on EL4 target cells. The peptide from mouse LFA-1 was also able to inhibit cytotoxicity confirming the implication of ICAM-1/LFA-1 interaction in this process. As additional controls, lovastatin and mouse ICAM-1 $\left(\mathrm{D}_{1} \mathrm{D}_{5} \mathrm{Fc}\right)$ inhibited cell death induced by Tc cells confirming the importance of ICAM-1 and LFA-1 during cell death induced by Tc cells. Mouse $\mathrm{D}_{1} \mathrm{D}_{5} \mathrm{Fc}(\mathrm{B})$ and human $\mathrm{D}_{1} \mathrm{D}_{2}$ and $\mathrm{D}_{1} \mathrm{D}_{2} \mathrm{Fc}(\mathrm{A})$ similarly prevented cell death induced by Tc cells indicating a similar affinity of human and mouse ICAM- 1 to mouse LFA-1 in this model. In both cases, human NK cells and mouse Tc cells, the effect of the peptides was less pronounced than that of ICAM-1, which maybe explained due to a reduced capacity to block the interaction between ICAM-1 and LFA-1 by a short peptide in contrast to full ICAM-1.
Our results help to explain the previous observations in which expression of human ICAM-1 in mouse cancer cells favored its elimination in vitro and in vivo mediated by mouse immune cells including NK cells (30-33). These results suggested that mouse LFA-1 interacts with human ICAM-1. Here, we have confirmed this suggestion and shown that human ICAM-1 efficiently binds to mouse LFA-1 also in cytotoxic cells, preventing its function during cell-mediated elimination of target cells.

\section{Blocking of Monocyte/Macrophage Cell Adhesion}

The growth of adherent cells such as monocytes or macrophages requires signals not only from growth factor receptors but also from integrins (47). Integrins have two basic roles: to mediate adhesion and signaling $(48,49)$. Indeed, it has been described that LFA- 1 is one of the most critical molecules involved in monocyte/macrophage adhesion (49). To further proof that human ICAM-1 is able to bind mouse LFA-1, we decided to analyze this binding in another type of leukocytes, the macrophages. Thus, we analyzed the ability of human ICAM-1 $\left(\mathrm{D}_{1} \mathrm{D}_{2}\right.$ and $\left.\mathrm{D}_{1} \mathrm{D}_{2} \mathrm{Fc}\right)$ to block adhesion of mouse macrophages to plastic surfaces. As control, human monocytes and macrophages were used.
A

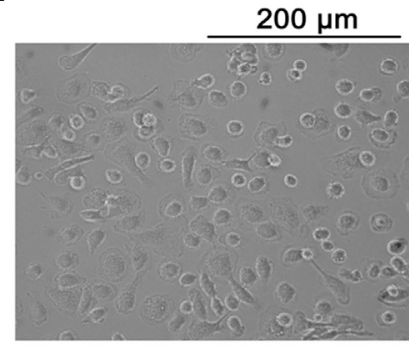

B

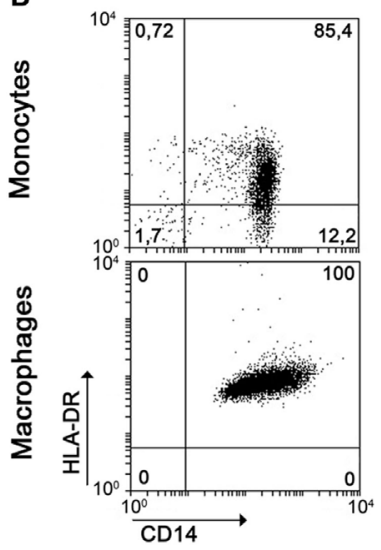

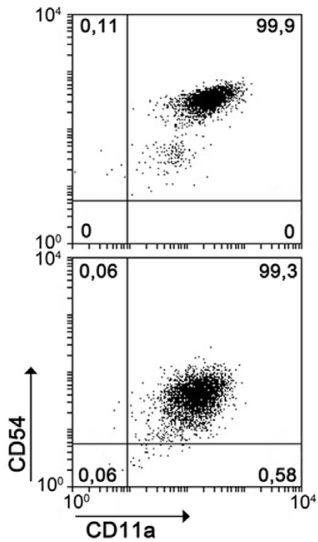

$c$
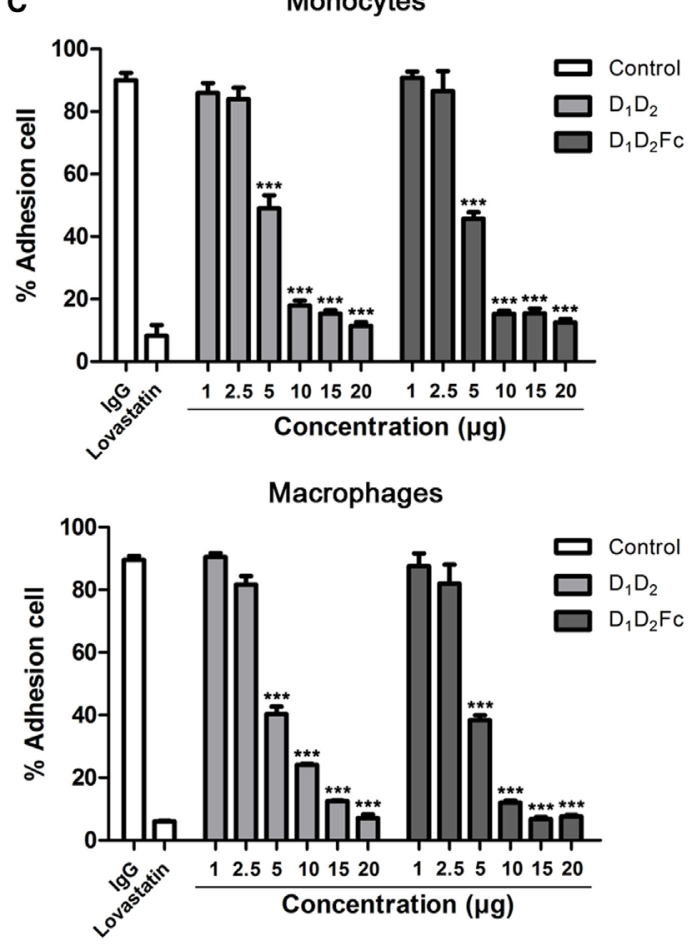

FIGURE 6 | LFA-1 is involved in human macrophage adhesion. (A) Human monocytes were differentiated for 6 days in the presence of GM-CSF as indicated in Section "Experimental Procedures." Representative images from cell cultures are shown (original magnification, 20x). (B) Macrophage phenotype was analyzed by flow cytometry testing the expression of HL-DR, CD14, CD54, and CD11a. A representative dot plot is shown. Numbers correspond to percentage of cells in each quadrant (C). Monocytes and macrophages were incubated at different concentrations of human $D_{1} D_{2}$ and $D_{1} D_{2} F c$, human lgG1 $20 \mu g$ and lovastatin $100 \mu M$ at $37^{\circ} \mathrm{C}$ overnight. Subsequently, every well was washed twice with PBS to remove non-adherent cells and quantification of cell adhesion was carried out by MTT as described in Section "Experimental Procedures." Values are presented as mean \pm SEM of three independent experiments performed by duplicate. Statistical analysis was performed using two-way analysis of variance with Bonferroni's posttest comparing with lgG1 control. ${ }^{* \star *} p<0.001$. 
As shown in Figure 6A, cells differentiated from human $\mathrm{CD}_{14}{ }^{+}$monocytes to macrophages in the presence of GM-CSF had a classical adherent "fried egg" morphology, characteristic of classically activated M1 pro-inflammatory macrophages (50). Macrophage phenotype was confirmed by testing surface antigens by flow cytometry. Monocyte-derived macrophages expressed higher levels of HLA-DR and CD14 than undifferentiated monocytes (51). In addition, expression of CD54 (ICAM-1) was diminished in comparison with freshly isolated monocytes (Figure 6B). CD11a (LFA-1) expression did not change. As shown in Figure 6C, adhesion of human monocytes (Figure 6C, top) and macrophages (Figure 6C, bottom) was completely inhibited by human ICAM-1 confirming that macrophages adhere to plastic by LFA-1. As control, lovastatin was able to block completely cell adhesion demonstrating that inhibition of LFA-1 is sufficient to block macrophage adhesion. It should be noted here that other integrins like Mac-1 or VLA-4 are not inhibited by lovastatin (43).

In spite of the elevated expression of ICAM-1 in fresh monocytes in comparison with macrophages, it did not correlate with the adhesion abilities of both cells (data not shown). As indicated previously, since we have used an ICAM-1 form consisting of $\mathrm{D}_{1}$ and $\mathrm{D}_{2}$, we can disregard that ICAM-1 is preventing macrophage cell adhesion by blocking Mac-1 that is also known to be involved in macrophage cell adhesion $(52,53)$.

After confirming that human ICAM-1 inhibits adhesion of human macrophages by binding to LFA-1, the same test was carried out with mouse macrophages in order to support that human ICAM-1 is able to functionally bind to mouse LFA-1. Differentiation of mouse bone marrow cells to macrophages with M-CSF was morphologically (Figure 7A) and phenotypically (Figure 7B) confirmed. As shown in Figure 7B, these cells exhibited a characteristic phenotype of macrophages $\left(\mathrm{CD}_{11} \mathrm{~b}^{+}\right.$ CD11c $c^{-}$(37). Again, $D_{1} D_{2}$ and $D_{1} D_{2} F c$ were able to inhibit the adhesion of mouse macrophages although less efficiently than in the case of human macrophages (Figure 7C). Lovastatin, an inhibitor of LFA-1, was able to completely inhibit the adhesion of these cells demonstrating that LFA-1 is the main molecule involved in macrophage adhesion also in the mouse system.

In this experimental model, uncoated plastic plates were used to analyze if human ICAM-1 was able to bind to mouse LFA-1 and, thus, interfere with macrophage attachment. However, in
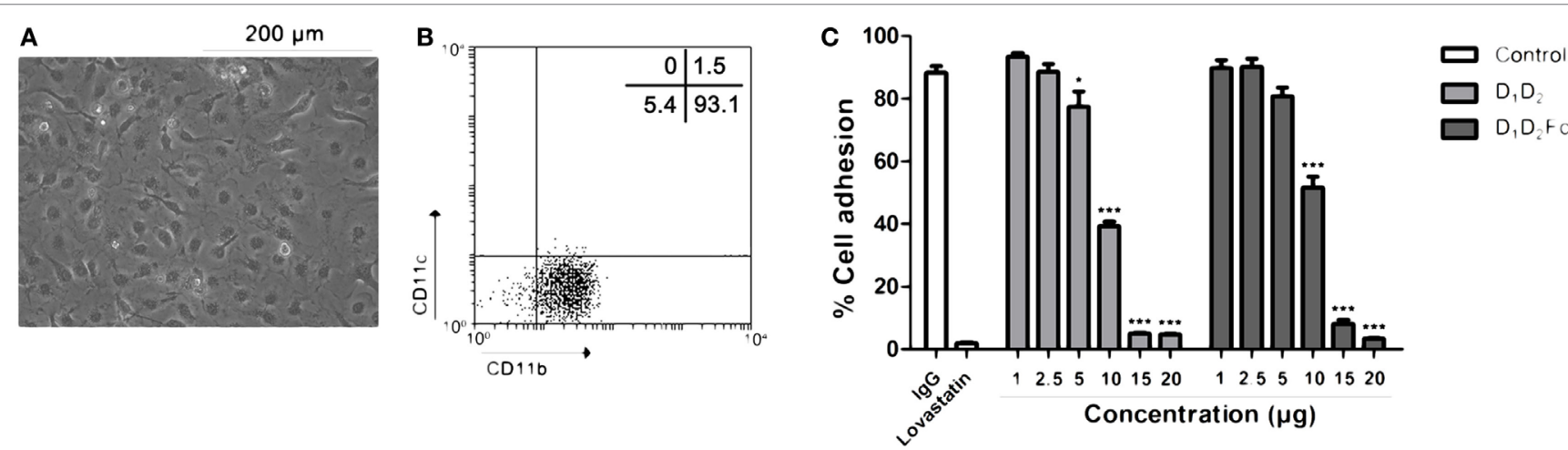

D

E
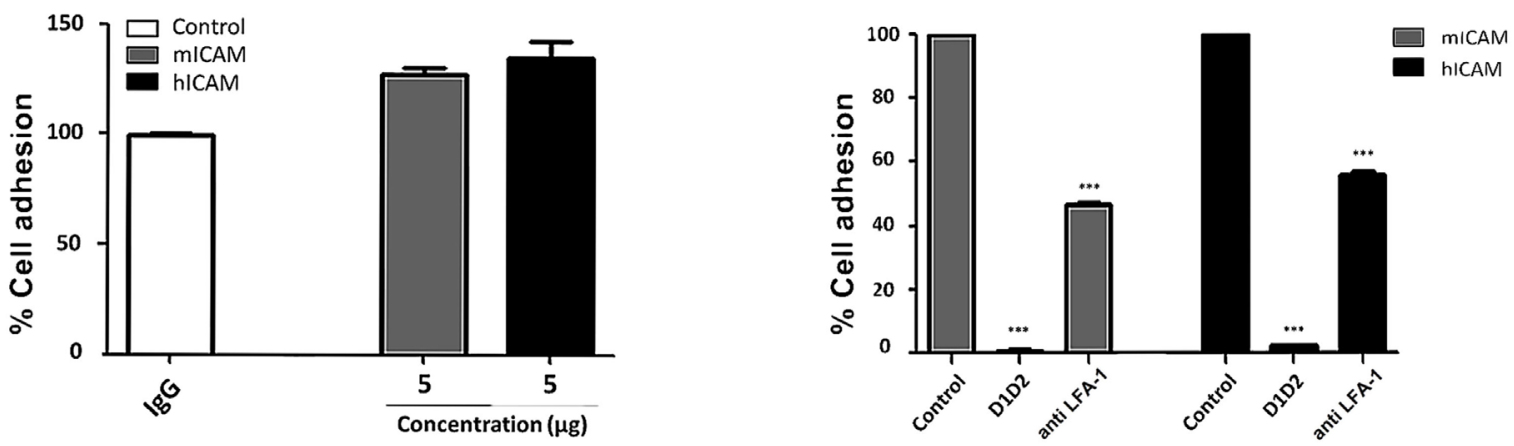

FIGURE 7 | Human intercellular adhesion molecule (ICAM)-1 blocks LFA-1-mediated mouse macrophage cell adhesion. (A) Mouse macrophages were differentiated from bone marrow cells as described in Section "Experimental Procedures." Representative images from cell cultures are shown (original magnification, 20x). (B) Macrophage phenotype was analyzed by flow cytometry testing the expression CD11b and CD11c. A representative dot plot is shown. Numbers correspond to percentage of cells in each quadrant. (C) Macrophages were incubated at different concentrations of human $D_{1} D_{2}$ and $D_{1} D_{2} F c$, human IgG1 $20 \mu g$ and lovastatin $100 \mu \mathrm{M}$ at $37^{\circ} \mathrm{C}$ overnight. Subsequently, every well was washed twice with PBS to remove non-adherent cells and quantification of cell adhesion was carried out by MTT as described in Section "Experimental Procedures." (D,E) The same experiment as in C was performed but using plates previously coated with $5 \mu$ g of mouse or human ICAM-1 (mICAM and hICAM; $D_{1} D_{5} F C$ ) as indicated. (D) \% of cell adhesion in wells coated with human IgG, mouse $D_{1} D_{5} F_{C}(m I C A M)$ or human $D_{1} D_{5} F C$ (hICAM). (E) Effect of human D1D2 and anti-mouse LFA-1 on macrophage cell adhesion to mouse $D_{1} D_{5} F C$ (mICAM) or human $D_{1} D_{5} F C$ (hICAM)-Coated plates. Values are presented as mean \pm SEM of two separate experiments performed by duplicate. Statistical analysis was performed using two-way analysis of variance with Bonferroni's posttest comparing with IgG1 control. ${ }^{\star} p<0.05$; ${ }^{* \star *} p<0.001$. 
this experimental system, macrophages could adhere to plastic through different adhesion molecules. Thus, to really proof that human ICAM-1 was interfering with LFA-1-dependent mouse macrophage attachment, we repeated this experiment employing mouse macrophages and plates coated with mouse or human ICAM-1 $\left(D_{1} D_{5} F c\right)$. As shown in Figure $7 D$, mouse macrophages similarly adhered to plates independently whether they were coated with mouse or human ICAM-1. Moreover, pre-incubation of macrophages with either anti-LFA-1 Ab or human soluble ICAM-1 (D1D2) (Figure 7E) blocked macrophage adhesion in both mouse and human ICAM-1 coated plates, confirming that human ICAM-1 is also binding to mouse LFA-1 in macrophages.

It should be noted here that soluble human ICAM-1 (D1D2) completely blocked macrophage adhesion, indicating that the interaction of Mac-1 (CD11b) with the domain 3 of immobilized ICAM-1 is not enough to support macrophage adhesion. Indeed it has been previously found that LFA-1, and not Mac-1, is mainly involved in cell adhesion to ICAM-1 coated plates (54), which was related to the relatively weak affinity of Mac-1 to ICAM-1. In contrast, both LFA- 1 and Mac- 1 similarly mediated cell adhesion to ICAM-3-coated plates. The differences found between the effect of anti-LFA-1 Ab and human soluble ICAM-1 (D1D2) could be related to a different affinity to LFA-1 or to a different stoichiometry since blocking Ab was not fully titrated to find out an optimal concentration that completely blocks macrophage adhesion. Whatever the reason, these results clearly show that mouse macrophages bound to human ICAM-1-coated plates by a mechanism dependent on LFA- 1 and, thus, human ICAM-1 is able to interact with mouse LFA-1 expressed on the membrane on macrophages.

It has been reported that human ICAM-1 shares a 53\% structural homology with murine ICAM-1 (28). Concerning amino acid sequences, the first two domains of human ICAM-1 has around $70 \%$ identity or homology with mouse ICAM-1. Despite these comparisons, it has been shown that human ICAM-1 does not bind to mouse LFA-1 using in vitro cell-free systems (29). This finding contrast with other reports suggesting that functionally human ICAM-1 is able to interact with mouse LFA-1 during tumor immunosurveillance $(30,31,33,55)$. Although we have not measured direct interaction between human ICAM-1 and murine LFA-1 expressed both in different cells, our results show that human ICAM-1 is able to interact specifically with mouse LFA-1 using in vitro cell models and lovastatin as control of a specific interaction. This binding has also been confirmed at the functional level in a wide variety of cells expressing LFA-1 including transformed $\mathrm{T}$ cells and primary $\mathrm{B}, \mathrm{NK}$, and $\mathrm{T}$ cells as well as macrophages.

\section{REFERENCES}

1. Smith CW. 3. Adhesion molecules and receptors. J Allergy Clin Immunol (2008) 121:S375-9. doi:10.1016/j.jaci.2007.07.030

2. Makrilia N, Kollias A, Manolopoulos L, Syrigos K. Cell adhesion molecules: role and clinical significance in cancer. Cancer Invest (2009) 27:1023-37. doi:10.3109/07357900902769749

3. Ramos TN, Bullard DC, Barnum SR. ICAM-1: isoforms and phenotypes. J Immunol (2014) 192:4469-74. doi:10.4049/jimmunol.1400135
Although we do not have yet an explanation for the apparent contradictory findings, our results indicate that human ICAM-1 is able to interact with mouse LFA-1 at the cellular level. Besides, the results obtained are independent of the organism used to produce $\mathrm{D}_{1} \mathrm{D}_{2}$ because the domain 1 , which is the binding site to LFA-1, does not require posttranslational modifications like glycosilation to bind LFA-1 $(56,57)$.

This finding should be taken into account when designing experiments and interpreting results using transgenic mice expressing human ICAM-1 or xenograft models in which host leukocytes expressing LFA-1 will bind to endogenously expressed human ICAM-1 transgene or to grafted human cells expressing ICAM-1.

\section{ETHICS STATEMENT}

All procedures were approved by the Ethic Committee for Animal Experiments from CITA. The care and use of animals were performed accordingly with the Spanish Policy for Animal Protection RD53/2013, which meets the European Union Directive 2010/63 on the protection of animals used for experimental and other scientific purposes.

\section{AUTHOR CONTRIBUTIONS}

DN performed and designed experiments, analysed the data and wrote the first draft of the paper. LC, PML and DSM performed and designed experiments. MPH assisted in the generation and characterization of mouse macrophages. EC generated the LCMV-specific cytotoxic T lymphocytes. MPD established the conditions for ICAM-1 purification. AVC performed the ITC experiments and analysed the data. JP and EMG conceived the study and wrote the final version of the manuscript. All authors read and approved the final manuscript.

\section{FUNDING}

This work was supported by Fondo Social Europeo (FSE; Gobierno de Aragón) and by grants2009tw0034 from the Spanish National Research Council (CSIC), SAF2011-25390, SAF201454763-C2-1-R, SAF2014-54763-C2-2-R and BFU2016-78232-P (AVC) from Spanish Ministry of Economy and Competitiveness (JP). JP and AVC were supported by Aragón I+D (ARAID). DSM and LC are supported by a predoctoral contract from Gobierno de Aragón and PML by a FPU predoctoral contract from Ministerio de Educación, Cultura y Deporte.

4. Fuchs R, Blaas D. Uncoating of human rhinoviruses. Rev Med Virol (2010) 20:281-97. doi:10.1002/rmv.654

5. Tse MT, Chakrabarti K, Gray C, Chitnis CE, Craig A. Divergent binding sites on intercellular adhesion molecule-1 (ICAM-1) for variant Plasmodium falciparum isolates. Mol Microbiol (2004) 51:1039-49. doi:10.1046/j. 1365-2958.2003.03895.x

6. Diamond MS, Staunton DE, de Fougerolles AR, Stacker SA, Garcia-Aguilar J, Hibbs ML, et al. ICAM-1 (CD54): a counter-receptor for Mac-1 (CD11b/ CD18). J Cell Biol (1990) 111:3129-39. doi:10.1083/jcb.111.6.3129 
7. Rothlein R, Dustin ML, Marlin SD, Springer TA. A human intercellular adhesion molecule (ICAM-1) distinct from LFA-1. JImmunol (1986) 137(4):1270-4.

8. Dustin ML, Rothlein R, Bhan AK, Dinarello CA, Springer TA. Induction by IL 1 and interferon-gamma: tissue distribution, biochemistry, and function of a natural adherence molecule (ICAM-1). J Immunol (1986) 137:245-54.

9. Marlin SD, Springer TA. Purified intercellular adhesion molecule-1 (ICAM-1) is a ligand for lymphocyte function-associated antigen 1 (LFA-1). Cell (1987) 51:813-9. doi:10.1016/0092-8674(87)90104-8

10. Makgoba MW, Sanders ME, Ginther Luce GE, Dustin ML, Springer TA, Clark EA, et al. ICAM-1 a ligand for LFA-1-dependent adhesion of B, T and myeloid cells. Nature (1988) 331:86-8. doi:10.1038/331086a0

11. Casasnovas JM, Stehle T, Liu JH, Wang JH, Springer TA. A dimeric crystal structure for the N-terminal two domains of intercellular adhesion molecule-1. Proc Natl Acad Sci U S A (1998) 95:4134-9. doi:10.1073/pnas.95.8. 4134

12. Jun CD, Shimaoka M, Carman CV, Takagi J, Springer TA. Dimerization and the effectiveness of ICAM-1 in mediating LFA-1-dependent adhesion. Proc Natl Acad Sci U S A (2001) 98:6830-5. doi:10.1073/pnas.121186998

13. Witkowska AM, Borawska MH. Soluble intercellular adhesion molecule-1 (sICAM-1): an overview. Eur Cytokine Netw (2004) 15:91-8.

14. Shin HS, Jung CH, Park HD, Lee SS. The relationship between the serum intercellular adhesion molecule-1 level and the prognosis of the disease in lung cancer. Korean J Intern Med (2004) 19:48-52. doi:10.3904/ kjim.2004.19.1.48

15. Haim M, Tanne D, Boyko V, Reshef T, Goldbourt U, Leor J, et al. Soluble intercellular adhesion molecule-1 and long-term risk of acute coronary events in patients with chronic coronary heart disease. Data from the Bezafibrate Infarction Prevention (BIP) Study. J Am Coll Cardiol (2002) 39:1133-8. doi:10.1016/S0735-1097(02)01728-X

16. Lefort CT, Ley K. Neutrophil arrest by LFA-1 activation. Front Immunol (2012) 3:157. doi:10.3389/fimmu.2012.00157

17. Campbell ID, Humphries MJ. Integrin structure, activation, and interactions. Cold Spring Harb Perspect Biol (2011) 3(3):a004994. doi:10.1101/ cshperspect.a004994

18. Huth JR, Olejniczak ET, Mendoza R, Liang H, Harris EAS, Lupher ML, et al. NMR and mutagenesis evidence for an I domain allosteric site that regulates lymphocyte function-associated antigen 1 ligand binding. Proc Natl Aca Sci U S A (2000) 97:5231-6. doi:10.1073/pnas.97.10.5231

19. Chakraborty S, Nunez D, Hu SY, Domingo MP, Pardo J, Karmenyan A, et al. FRET based quantification and screening technology platform for the interactions of leukocyte function-associated antigen-1 (LFA-1) with intercellular adhesion molecule-1 (ICAM-1). PLoS One (2014) 9:e102572. doi:10.1371/ journal.pone.0102572

20. Stanley P, Hogg N. The I domain of integrin LFA-1 interacts with ICAM-1 domain 1 at residue Glu-34 but not Gln-73. J Biol Chem (1998) 273:3358-62. doi:10.1074/jbc.273.6.3358

21. Hogg N, Laschinger M, Giles K, McDowall A. T-cell integrins: more than just sticking points. J Cell Sci (2003) 116:4695-705. doi:10.1242/jcs.00876

22. Gross CC, Brzostowski JA, Liu D, Long EO. Tethering of intercellular adhesion molecule on target cells is required for LFA-1-dependent NK cell adhesion and granule polarization. JImmunol (2010) 185:2918-26. doi:10.4049/ jimmunol.1000761

23. Brehm MA, Shultz LD, Greiner DL. Humanized mouse models to study human diseases. Curr Opin Endocrinol Diabetes Obes (2010) 17:120-5. doi:10.1097/ MED.0b013e328337282f

24. Yagita H, Nakamura T, Karasuyama H, Okumura K. Monoclonal antibodies specific for murine CD2 reveal its presence on B as well as T cells. Proc Natl Acad Sci U S A (1989) 86:645-9. doi:10.1073/pnas.86.2.645

25. Kato K, Koyanagi M, Okada H, Takanashi T, Wong YW, Williams AF, et al. $\mathrm{CD} 48$ is a counter-receptor for mouse $\mathrm{CD} 2$ and is involved in $\mathrm{T}$ cell activation. J Exp Med (1992) 176:1241-9. doi:10.1084/jem.176.5.1241

26. Kaufmann Y, Tseng E, Springer TA. Cloning of the murine lymphocyte function-associated molecule-1 alpha-subunit and its expression in COS cells. J Immunol (1991) 147:369-74.

27. Siu G, Hedrick SM, Brian AA. Isolation of the murine intercellular adhesion molecule 1 (ICAM-1) gene. ICAM-1 enhances antigen-specific T cell activation. J Immunol (1989) 143:3813-20.
28. XuH, BickfordJK, LutherE, Carpenito C, Takei F, SpringerTA.Characterization of murine intercellular adhesion molecule-2. J Immunol (1996) 156:4909-14.

29. Johnston SC, Dustin ML, Hibbs ML, Springer TA. On the species specificity of the interaction of LFA-1 with intercellular adhesion molecules. J Immunol (1990) 145:1181-7.

30. Sunami T, Yashiro M, Chung KH. ICAM-1 (intercellular adhesion molecule-1) gene transfection inhibits lymph node metastasis by human gastric cancer cells. Jpn J Cancer Res (2000) 91:925-33. doi:10.1111/j.1349-7006.2000. tb01036.x

31. Burno DK, Kyprianou N, Sartor WM, Fabian DF, Turner J, Vu T, et al. Transfection of a murine fibrosarcoma with intercellular adhesion molecule-1 enhances the response to adoptive immunotherapy. Surgery (1995) 118:237-243; discussion 243-234. doi:10.1016/S0039-6060(05)80329-0

32. Sartor WM, Kyprianou N, Fabian DF, Lefor AT. Enhanced expression of ICAM-1 in a murine fibrosarcoma reduces tumor growth rate. J Surg Res (1995) 59:66-74. doi:10.1006/jsre.1995.1133

33. Burno DK, Fabian DF, Lefor AT. ICAM-1 increases in vitro adhesion and cytotoxicity in a murine fibrosarcoma. J Surg Res (1996) 60:398-402. doi:10.1006/ jsre.1996.0065

34. Núñez D, Domingo MP, Sánchez-Martínez D, Cebolla V, Chiou A, VelázquezCampoy A, et al. Recombinant production of human ICAM-1 chimeras by single step on column refolding and purification. Process Biochem (2013) 48:708-15. doi:10.1016/j.procbio.2013.03.006

35. Wu SH, Nunez D, Hu SY, Domingo MP, Chen YC, Wei PK, et al. The effect of acidic $\mathrm{pH}$ on the inhibitory efficacy of peptides against the interaction ICAM-1/LFA-1 studied by surface plasmon resonance (SPR). Biosens Bioelectron (2014) 56:159-66. doi:10.1016/j.bios.2014.01.008

36. Tibbetts SA, Seetharama Jois D, Siahaan TJ, Benedict SH, Chan MA. Linear and cyclic LFA-1 and ICAM-1 peptides inhibit T cell adhesion and function. Peptides (2000) 21:1161-7. doi:10.1016/S0196-9781(00)00255-2

37. Arias MA, Jimenez de Bagues MP, Aguilo N, Menao S, Hervas-Stubbs S, de Martino A, et al. Elucidating sources and roles of granzymes A and B during bacterial infection and sepsis. Cell Rep (2014) 8:420-9. doi:10.1016/j. celrep.2014.06.012

38. Alley MC, Scudiero DA, Monks A, Hursey ML, Czerwinski MJ, Fine DL, et al. Feasibility of drug screening with panels of human tumor cell lines using a microculture tetrazolium assay. Cancer Res (1988) 48:589-601.

39. Sanchez-Martinez D, Azaceta G, Muntasell A, Aguilo N, Nunez D, Galvez EM, et al. Human NK cells activated by EBV lymphoblastoid cells overcome anti-apoptotic mechanisms of drug resistance in haematological cancer cells. Oncoimmunology (2015) 4:e991613. doi:10.4161/2162402X. 2014.991613

40. Pircher H, Moskophidis D, Rohrer U, Burki K, Hengartner H, Zinkernagel RM. Viral escape by selection of cytotoxic $\mathrm{T}$ cell-resistant virus variants in vivo. Nature (1990) 346:629-33. doi:10.1038/346629a0

41. Tibbetts SA, Chirathaworn C, Nakashima M, Jois DS, Siahaan TJ, Chan MA, et al. Peptides derived from ICAM- 1 and LFA- 1 modulate T cell adhesion and immune function in a mixed lymphocyte culture. Transplantation (1999) 68:685-92. doi:10.1097/00007890-199909150-00015

42. Kallen J, Welzenbach K, Ramage P, Geyl D, Kriwacki R, Legge G, et al. Structural basis for LFA-1 inhibition upon lovastatin binding to the CD11a I-domain. J Mol Biol (1999) 292:1-9. doi:10.1006/jmbi.1999.3047

43. Weitz-Schmidt G, Welzenbach K, Brinkmann V, Kamata T, Kallen J, Bruns C, et al. Statins selectively inhibit leukocyte function antigen-1 by binding to a novel regulatory integrin site. Nat Med (2001) 7:687-92. doi:10.1038/89058

44. Spits H, van Schooten W, Keizer H, van Seventer G, van de Rijn M, Terhorst C, et al. Alloantigen recognition is preceded by nonspecific adhesion of cytotoxic T cells and target cells. Science (1986) 232:403-5. doi:10.1126/science. 3485822

45. Dustin ML, Springer TA. T-cell receptor cross-linking transiently stimulates adhesiveness through LFA-1. Nature (1989) 341:619-24. doi:10.1038/341619a0

46. Liu D, Bryceson YT, Meckel T, Vasiliver-Shamis G, Dustin ML, Long EO. Integrin-dependent organization and bidirectional vesicular traffic at cytotoxic immune synapses. Immunity (2009) 31:99-109. doi:10.1016/j. immuni.2009.05.009

47. Stupack DG. Integrins as a distinct subtype of dependence receptors. Cell Death Differ (2005) 12:1021-30. doi:10.1038/sj.cdd.4401658 
48. Streuli CH, Akhtar N. Signal co-operation between integrins and other receptor systems. Biochem J (2009) 418:491-506. doi:10.1042/BJ20081948

49. Springer TA. Traffic signals for lymphocyte recirculation and leukocyte emigration: the multistep paradigm. Cell (1994) 76:301-14. doi:10.1016/ 0092-8674(94)90337-9

50. Verreck FA, de Boer T, Langenberg DM, van der Zanden L, Ottenhoff TH. Phenotypic and functional profiling of human proinflammatory type- 1 and anti-inflammatory type- 2 macrophages in response to microbial antigens and IFN-gamma- and CD40L-mediated costimulation. J Leukoc Biol (2006) 79:285-93. doi:10.1189/jlb.0105015

51. Gordon S, Taylor PR. Monocyte and macrophage heterogeneity. Nat Rev Immunol (2005) 5:953-64. doi:10.1038/nri1733

52. Lin TH, Yurochko A, Kornberg L, Morris J, Walker JJ, Haskill S, et al. The role of protein tyrosine phosphorylation in integrin-mediated gene induction in monocytes. J Cell Biol (1994) 126:1585-93. doi:10.1083/jcb. 126.6.1585

53. Rosen H, Gordon S. Monoclonal antibody to the murine type 3 complement receptor inhibits adhesion of myelomonocytic cells in vitro and inflammatory cell recruitment in vivo. J Exp Med (1987) 166:1685-701. doi:10.1084/ jem.166.6.1685

54. Hermand P, Huet M, Callebaut I, Gane P, Ihanus E, Gahmberg CG, et al. Binding sites of leukocyte beta 2 integrins (LFA-1, Mac-1) on the human ICAM-4/LW blood group protein. J Biol Chem (2000) 275:26002-10. doi:10.1074/jbc.M002823200
55. Altmann DM, Hogg N, Trowsdale J, Wilkinson D. Cotransfection of ICAM-1 and HLA-DR reconstitutes human antigen-presenting cell function in mouse L cells. Nature (1989) 338:512-4. doi:10.1038/338512a0

56. Bella J, Kolatkar PR, Marlor CW, Greve JM, Rossmann MG. The structure of the two amino-terminal domains of human ICAM-1 suggests how it functions as a rhinovirus receptor and as an LFA-1 integrin ligand. Proc Natl Acad Sci U S A (1998) 95:4140-5. doi:10.1073/pnas.95.8.4140

57. Diamond MS, Staunton DE, Marlin SD, Springer TA. Binding of the integrin Mac-1 (CD11b/CD18) to the third immunoglobulin-like domain of ICAM-1 (CD54) and its regulation by glycosylation. Cell (1991) 65:961-71. doi:10.1016/0092-8674(91)90548-D

Conflict of Interest Statement: The authors declare that the research was conducted in the absence of any commercial or financial relationships that could be construed as a potential conflict of interest.

The reviewer ZF and handling editor declared their shared affiliation.

Copyright () 2017 Núñez, Comas, Lanuza, Sánchez-Martinez, Pérez-Hernández, Catalán, Domingo, Velázquez-Campoy, Pardo and Gálvez. This is an open-access article distributed under the terms of the Creative Commons Attribution License (CC BY). The use, distribution or reproduction in other forums is permitted, provided the original author(s) or licensor are credited and that the original publication in this journal is cited, in accordance with accepted academic practice. No use, distribution or reproduction is permitted which does not comply with these terms. 